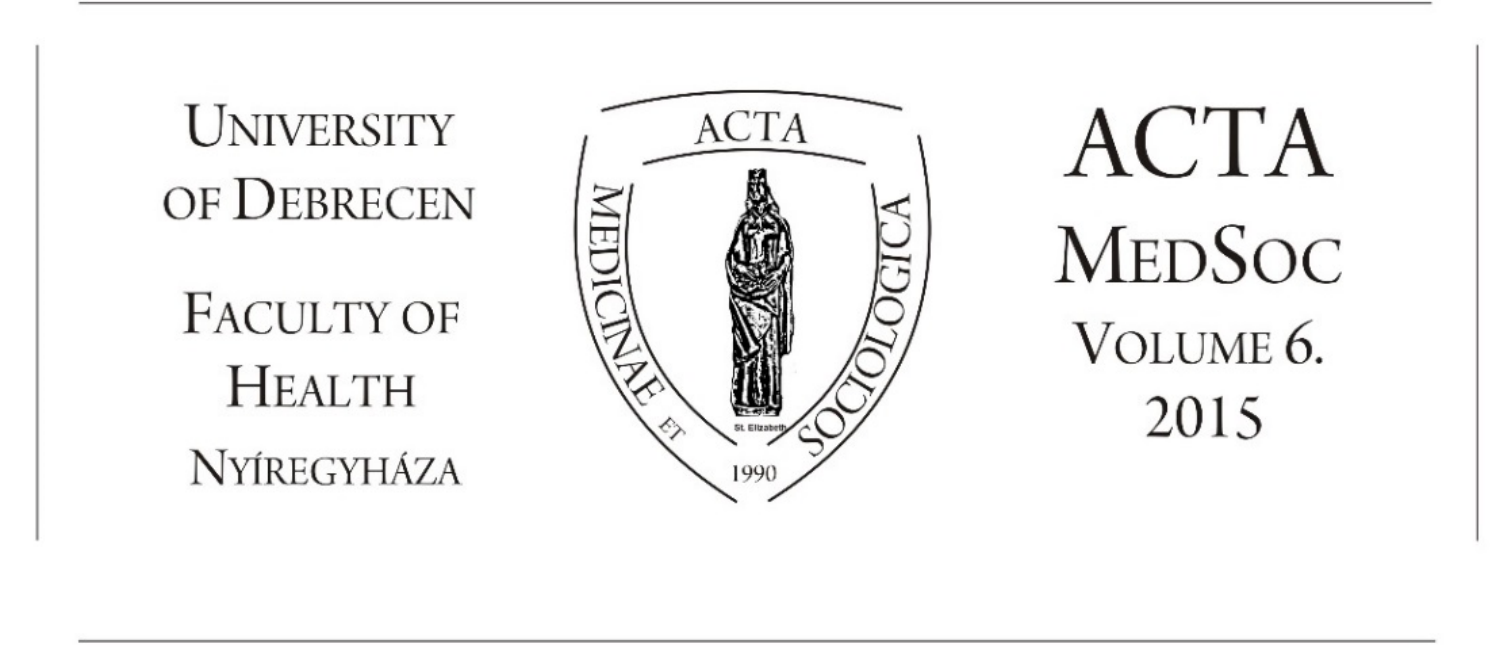

\title{
A Nyíregyházi járásban élő idősek életkörülményei
}

\section{Patyán László}

Abstract: This study based on the research „Life quality in Nyíregyháza” and the similar research which was made in the District of Nyíregyháza. The above mentioned district is the statistical unit round town Nyíregyháza and contains little settlements, and small towns. The research gave us good possibility to compare these units and found the main characteristic of the quality of life in the county capital versus it's agglomeration. The study shows the situation of the elder households (age $65+$ ). The main topics were: the conditions of households, benefits, subjective wellbeing, health situations, living conditions, costs of living, and housing .

The study showed the special situations of households, where people over 65 years, and lived alone, or together with the other old person.

Keywords: Elderly, Town and district of Nyíregyháza, Households of elderly, Quality of life, Health Status, Subjective well-being, Way of living, Cost of living

\section{Bevezető}

A „Nyíregyháza Város Életminősége” néven ismert panel adatfelvételeket kutatócsoportunk $^{46}$ Nyíregyháza Megyei Jogú Város Önkormányzatával együttmüködve 2008-óta végzi. A kétévente elkészült adatfelvételek során lehetővé vált a lakosság egésze életminőségének, illetve egyes csoportoknak a vizsgálata. A

\footnotetext{
${ }^{46}$ Kutatásvezető Dr. Fábián Gergely, Dr. Huszti Éva. Az elemzéseket a Debreceni Egyetem Egészségügyi Kar és Nyíregyháza Megyei Jogú Város Önkormányzata kutatói végzik.
} 
kutatás egyik eleme minden esetben az időskorú lakosság élethelyzetének, életminőségének vizsgálata volt a kérdőív adta lehetőségek és korlátok között.

Az elemzések során a demográfiai és gazdasági folyamatokat elemző statisztikai mutatók arra engedtek következtetni, hogy Nyíregyháza város lakossága sok tekintetben kedvezőbb feltételek között él, mint a megye lakossága.

A nyíregyházi járás lakossága körében 2015. évben végzett reprezentatív adatfelvétel kedvező lehetőséget kínál a megyeszékhely és a járás lakosságának életminőségét befolyásoló, egyes mutatók megvizsgálására. Meg kell azonban jegyezni, hogy a vizsgált járás nem tartozik a megye leghátrányosabb térségéhez. A települések egy része gyakorlatilag a megyeszékhely agglomerációjában található, $\mathrm{s}$ a távolabbi települések kisvárosi jellege (Rakamaz, Újfehértó) jobb feltételeket ígérhet az ott élők számára. Mindemellett a tényleges gazdasági teljesítmény ismeretében kétségtelen a megyeszékhely előnyös helyzete. ${ }^{47} 48$

E tanulmányban az idősek (65 év felettiek) életminőségét meghatározó változók elemzésén keresztül igyekszem bemutatni a városi és a vidéken vidéki életvitel életkor specifikus jellemzőit. A kutatás során bizonyos esetekben külön elemzésre kerül a csak időskorúakat tartalmazó háztartások helyzete.

\section{A kutatásról}

A vizsgálatot 2015-ben végeztük. A minta nemre és életkorra reprezentatív, a KEKKH által kiadott címlista alapján készült. Az egyenként ezer-ezer háztartást tartalmazó mintákból a járás esetében 909, a város esetében 754 értékelhető kérdőívet kaptunk vissza. A háztartásra vonatkozó információk ismertetése a háztartásfők megkérdezésével történt meg. Kérdezőbiztosi feladatokat a Debreceni Egyetem Egészségügyi Karának hallgatói, valamint a járáshoz tartozó települések szociális területen dolgozó munkatársai végezték, az adatrögzítést szintén a Kar hallgatóinak köszönhetjük. A városi minta a 4. lekérdezési hullámát élte meg, míg a járásban első ízben került sor a háztartások megkérdezésére.

\section{Az idősek helyzete}

\section{Demográfiai jellemzők}

A KSH adatai szerint (2011) a háztartások 26\%-ában csak időskorúak éltek ${ }^{49}$. Demográfiai értelemben a járás lakossága az átlagostól nagyobb elöregedést mutat. Száz gyermekkorúra a járásban 89, míg a megyében 79 időskorú jutott 2011-ben (Malakucziné, 2015). A járásszékhely és a járási városok öregedése jelentős eltéréseket mutat. Egyes településeken a járási öregedési index átlagánál (89) két és

47 A város kedvező gazdasági mutatóit az adóerő képesség mutatja, melyet tanulmánykötetünkben Krizsai Anita és Csatlós Ildikó mutattak be részletesebben.

48 Nyíregyházi járás népesedési jellemzőit e tanulmánykötetben pontosan jellemzi Malakucziné Póka Mária: A Nyíregyházi járás települési szervezeti, demográfiai, háztartási jellemzői c. tanulmánya.

${ }^{49}$ A KSH módszertana alapján időskorúnak a 60 év feletti lakosokat tekintették. 
félszer magasabb az index értéke, míg más települések - beleértve a járásszékhelyet is - fiatalabb korszerkezetet mutatnak (Malakucziné, 2015).

A kutatás során megkérdezett háztartások esetében a járásban a háztartások 13,6\%-ában ( $\mathrm{n}=124)$ éltek csak 65 év feletti polgárok, a városi mintában ez az arány jóval magasabb, a háztartások 17,8\%-ában találtunk csak időseket $(\mathrm{n}=134)$. Összességében tehát - a városi és a járási minta tekintetében - a válaszadó háztartásfők 20\%-a volt 65 év feletti, ami azt jelenti, hogy az időskorú háztartásfőt tartalmazó családok ötödében éltek generációk együtt egy háztartásban.

A csak időskorúakat tartalmazó háztartásokban élők átlagéletkora a járási mintában 72,3 év volt, míg a nyíregyházi mintában csaknem azonos, 72,7 év.

\section{Iskolázottság}

A legmagasabb iskolai végzettség az életkilátásokat meghatározó tényező. Az iskolai végzettség emelkedésével például általában véve nő az egészségben eltölthető életévek száma, magasabb a nyugdíj összege.

1. sz. ábra: A járásban és Nyíregyházán élö idösek csoportjai a legmagasabb iskolai végzettségük szerint

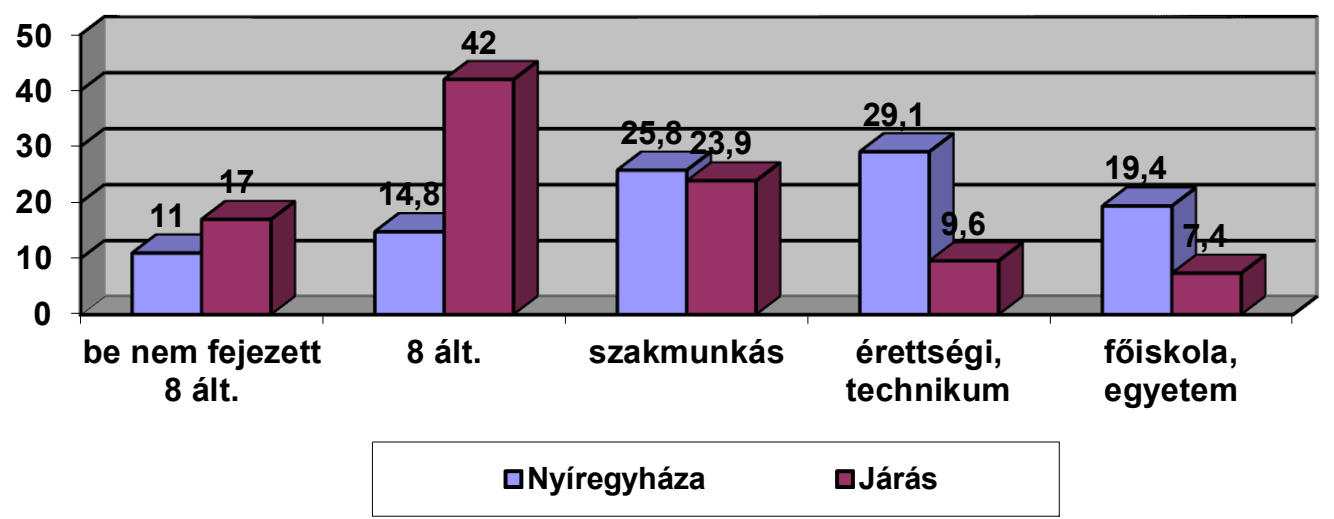

Forrás: Nyíregyháza Város Életminősége 2015, Nyíregyháza Járás Életminösége 2015. kutatás

A vidéken élő idősek majd' hatvan százaléka alapfokú, vagy be nem fejezett 8 általános végzettséggel rendelkezik, ötödük pedig szakmunkás végzettségü. Ezzel szemben a nyíregyházi idősek mintegy fele érettségizett, vagy felsőfokú végzettséggel rendelkezik. A KSH adatai szerint hazánkban Szabolcs-SzatmárBereg megyében a legmagasabb azoknak az időseknek az aránya, akik a 8 általánost sem fejezték be $(22,4 \%)$, ugyanakkor megyénknek van a legfiatalabb korstruktúrája és az idősek aránya is Szabolcsban a legalacsonyabb $(19,8 \%)(\mathrm{KSH}, 2014) .{ }^{50} \mathrm{~A}$ diplomával rendelkező idősek arányát tekintve pedig a harmadik legrosszabb mutatóval rendelkezik a megye $(8,4 \%)$.

\footnotetext{
${ }^{50}$ Idősek $=60$ év feletti népesség a KSH módszertana szerint.
} 


\section{Megélhetés}

Számos tényező befolyásolhatja az időskorúak életminőségét. Ezek egy része olyan generális jellegü változó, mely az idősek széles körének életminőségét meghatározhatja. A jóléti ellátórendszerek (szociális, egészségügyi) müködésének színvonala, fejlettsége ma szinte minden időskorú életére hatással van. Az életminőséget meghatározó kemény változók között azonban elsődlegesen a megélhetést biztosító jövedelemről kell szót ejteni. A nyugdíj, mint transzferjövedelem egyaránt lehet az életkori szegénységet konzerváló tényező, csakúgy, mint a tisztes megélhetést garantáló ellátási forma. Az idősek életminőségét meghatározó szerepét hazánkban a nyugdíjból élők relatíve magas nyugdíjfüggősége eredményezi. A KSH adatai szerint 2013-ban a nyugdíjas korúak 6\%-a rendelkezett munkajövedelemmel, tehát a megélhetés alapvető forrása a nyugdíj volt (KSH, 2013). A nyugdíj azonban nem biztosít egyforma ellátási szintet. A járulékfizetésben eltöltött évek, valamint a korábbi jövedelem mértéke mellett, vagy épp ezek eredményeképpen komoly regionális eltéréseket mutat a nyugdíjrendszer. Az egész országban SzabolcsSzatmár-Bereg megyében a legalacsonyabb az öregségi nyugdíjasok aránya (57,8\%), és legmagasabb a hozzátartozói, illetve megváltozott munkaképesség jogán megállapított ellátásban részesülők aránya (KSH, 2014). 2014-ben az átlagnyugdíj 115.786 Forint volt hazánkban. Budapesten ettöl átlagosan 21.338 Forinttal többet kaptak a nyugdíjasok, míg Szabolcs megyében átlag 12.662 Forinttal kevesebbet vitt ki a postás. Az alacsonyabb nyugdíj befolyásolhatja a fogyasztási kultúrát és a mindennapi életvitelt egyaránt.

\section{2. sz. ábra: Csak 65 év felettit tartalmazó háztartások} nettó átlagjövedelme (2015, \%).

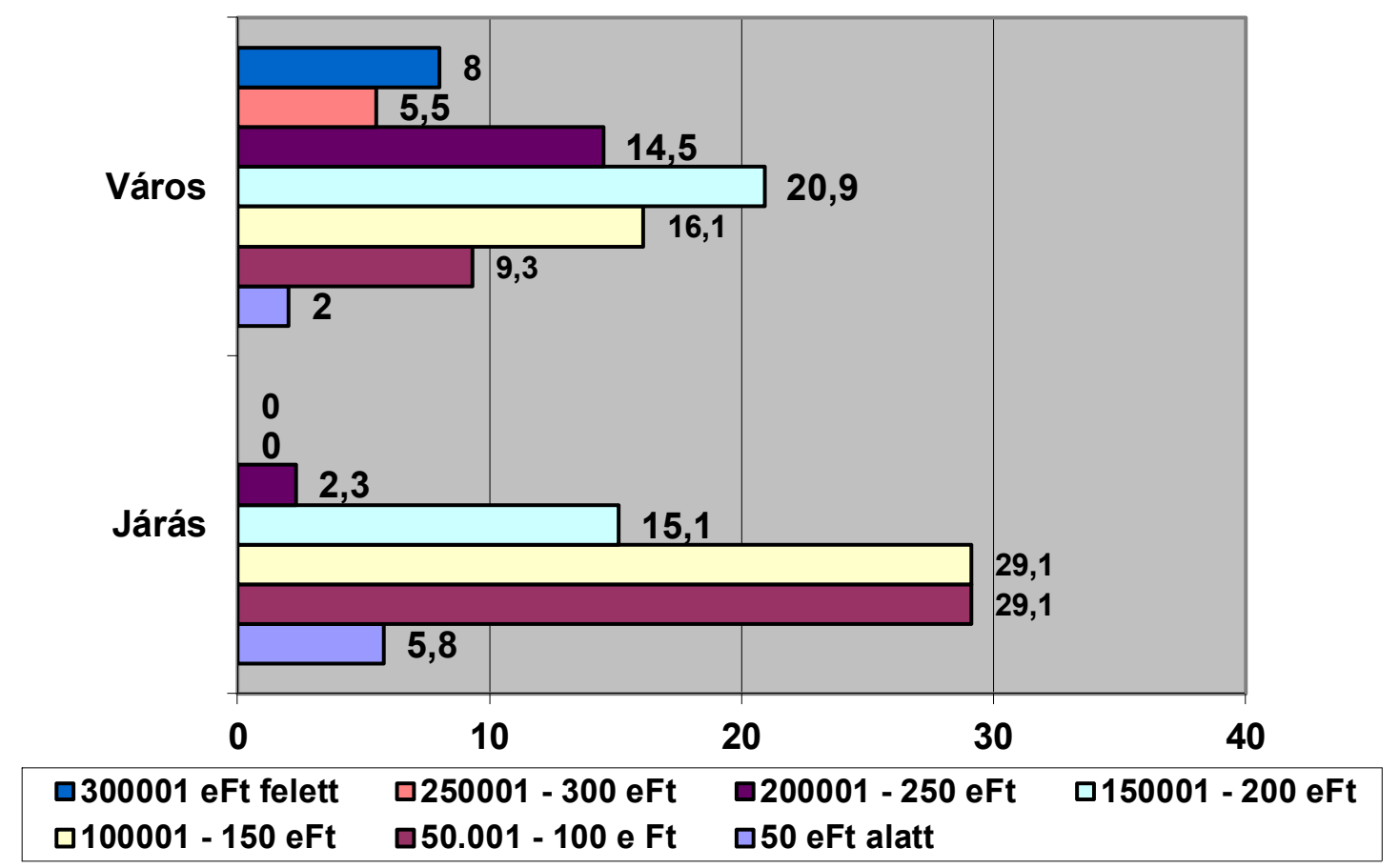

Megjegyzés: A válaszmegtagadók aránya a járás esetében a megkérdezettek 18,6\%-át tették ki. A városi idösek esetében az arány 23,6\% volt. 
Az egy vagy két időskorút tartalmazó háztartások közel azonos arányban oszlanak meg a városi és a járási mintában. A fenti táblázat adatai szerint a vidékiek alacsonyabb átlagjövedelemből gazdálkodhatnak. A nyugdíj mellett a járásban élő idösek 2,6\%-a rendelkezik munkajövedelemmel a városi 9,5\%-os aránnyal szemben. A munka világából való kivonulást sok tényező befolyásolja. A magasabb végzettségüek és a szellemi foglalkozásúak általában nagyobb arányban dolgoznak a nyugdíjkorhatár elérése után, ezzel szemben az alacsony iskolai végzettség, valamint a fizikai foglalkozás esetében nagyobb az esély a munka világából való kivonulásra, kiszorulásra.

Hozzátartozói ellátásban részesült a járásban élő idősek majd' harmada és a nyíregyházi csak időskorút tartalmazó háztartások negyede, rokkantnyugdíjat kapott a járásiak kevesebb, mint 5\%-a a városi 11\%-os aránnyal szemben. Önkormányzati támogatások valamelyikéből a vizsgált időskorú csoportok egyaránt 10\% körüli arányban részesedtek.

3. sz. ábra: Idösek és az összes megkérdezett egy före esö átlagkeresete Nyíregyházán és a járásban

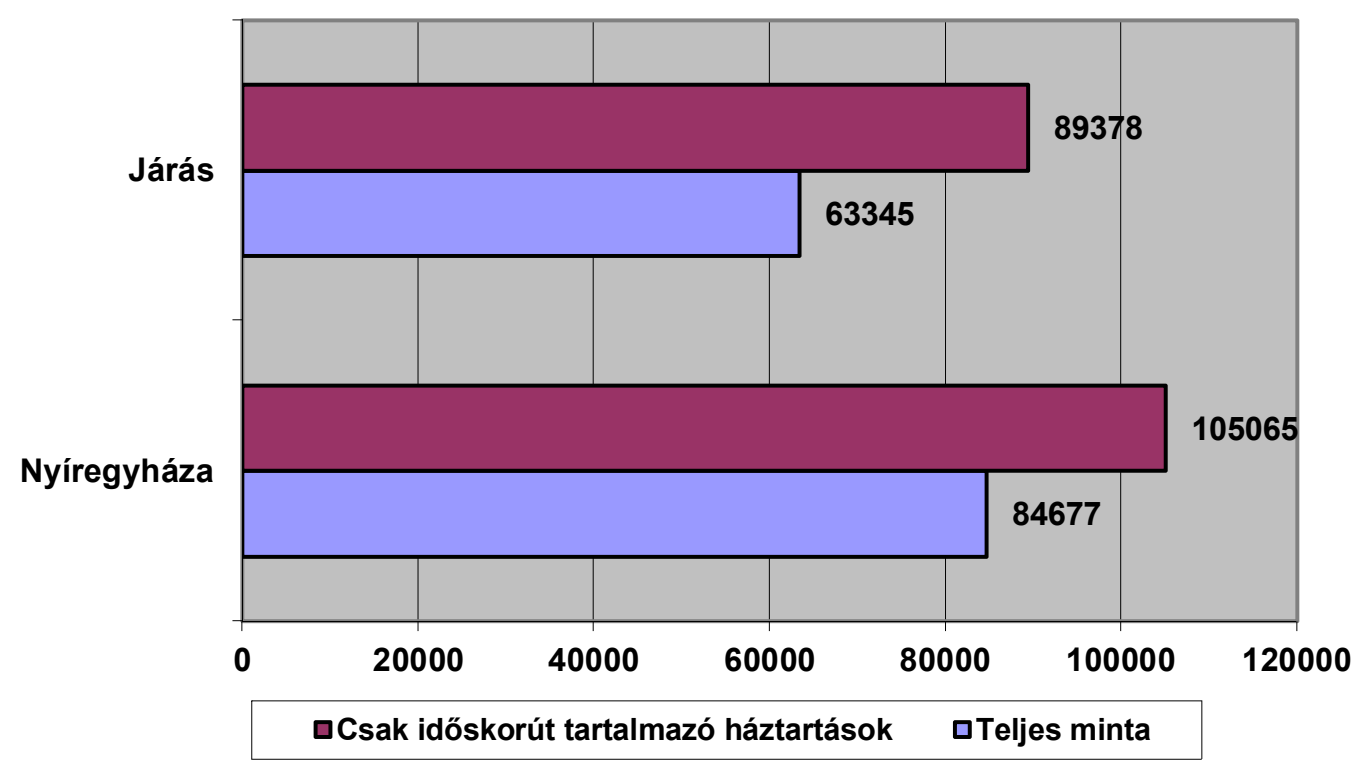

Forrás: Nyíregyháza Város Életminösége 2015, Nyíregyháza Járás Életminösége 2015. kutatás

A látszólagos jövedelem egyenlőtlenség oka az aktív korú háztartásokban található eltartottak (inaktívak, nem foglalkoztatottak) számából fakad, s egyben jól mutatja az időskori nyugdíj jövedelembiztonságot nyújtó szerepét is. Az idősek egy főre eső bevételeinek elemzése során azonban figyelembe kell venni, hogy a létminimum 2013-ban egy egyedül élő nyugdíjas esetében 78.759 Ft, két időst tartalmazó háztartás esetében $135.641 \mathrm{Ft}$ volt (KSH, 2014) Magyarországon. 


\section{A megélhetés szubjektív megítélése}

Az alábbi ábra a gazdálkodás szubjektív jellemzőit mutatja a vizsgált két csoport esetében.

4. sz. ábra: A jövedelemmel való gazdálkodás jellemzői a megkérdezettek megítélése szerint a csak időskorút tartalmazó háztartások esetében (5 fokozatú Likert-skála átlagok):

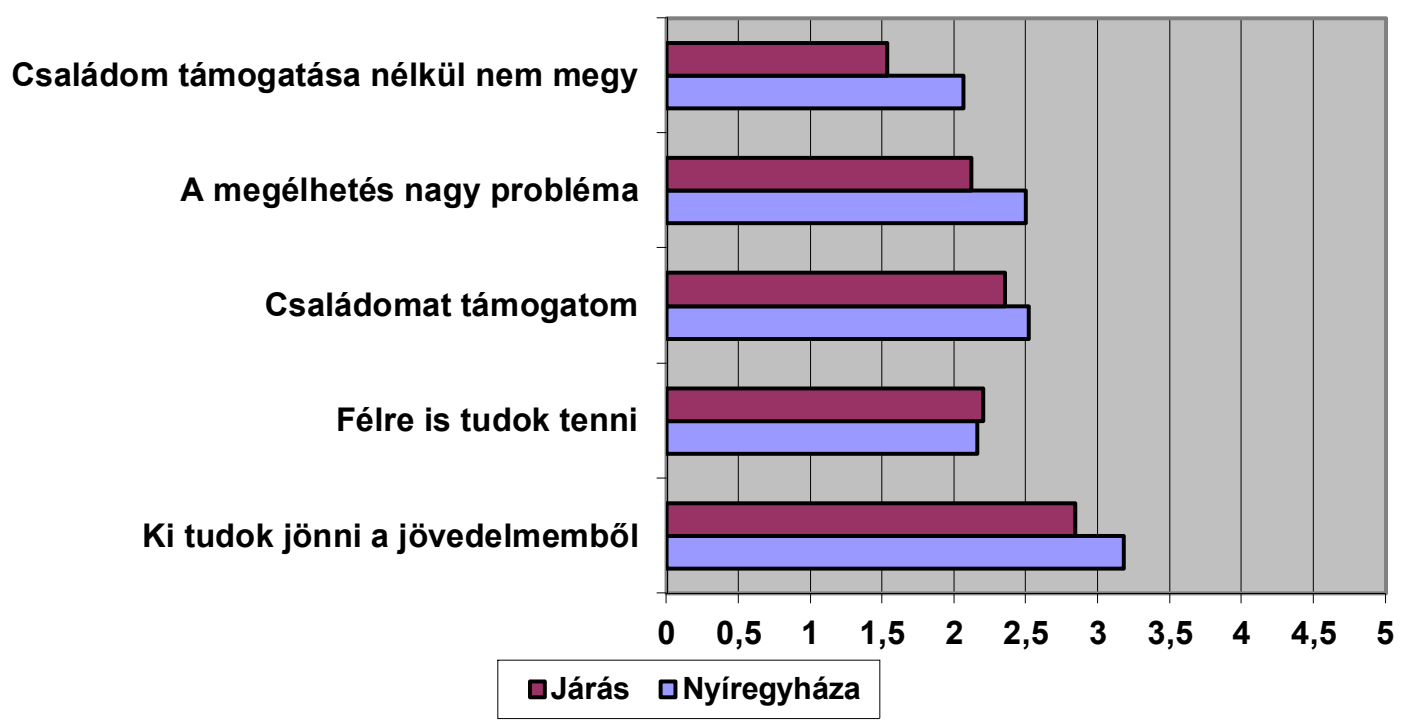

Forrás: Nyíregyháza Város Életminősége 2015, Nyíregyháza Járás Életminösége 2015. kutatások

A válaszok alapján minden ötödik időskorúnak kihívást jelent a megélhetés, és a család támogatása nélkül nagyon nehéz helyzetben lennének. Minden harmadik időskorú nyilatkozta azt, hogy nem tud kijönni a havi jövedelméböl, vagyis a fogyasztása valamely területén spórolásra kényszerül. Ezek a ráták mind a járási, mind a városi mintában közel azonos arányban szerepeltek. A skála átlagaiból úgy tünik, hogy a vidéki lakosok relatíve rosszabb helyzetük ellenére sem támaszkodnak oly mértékben a családtagjaikra, mint a nyíregyházi társaik.

Korábban utaltunk rá, hogy a jövedelmi szegénység a nyugdíjból élőket kevésbé veszélyeztetni (Patyán, 2014:130), mint az aktív korúak egyes csoportjait. Mindezek ellenére a saját helyzetük szubjektív megítélése tekintetében a csak időskorút tartalmazó háztartások esetében a vidéken élők negyede, a nyíregyházi idősek hatoda gondolta úgy, hogy helyzete sokkal rosszabb, vagy rosszabb, mint másoké.

A kisnyugdíjasok jövedelmi szegénysége gyakorlatilag egy, a korcsoportra jellemző fogyasztási stílussal párosul. E fogyasztási preferenciák lényege a lakhatás és az egészségügyi ellátás költségeinek elsődlegessége, melyet az élelmezésre fordított költségek követnek, s a sort a tartós fogyasztási cikkek, valamint a ruházkodás zárják. Ez utóbbiakra költenek az idősek arányaiban a legkevesebbet. Fogyasztási preferenciák tekintetében szembetünő az idősek felhalmozással 
kapcsolatos magatartása. ${ }^{51}$ A legfontosabb célok között a váratlan kiadások fedezését, a gyermekek jövőjének támogatását, valamint a temetéssel összefüggő kiadások fedezését említették egy 2009-ben késült felmérés szerint.

5. sz. ábra: Fogyasztással kapcsolatos állitások megitélése a nyíregyházi és a járási idösek lakta háztartásokban (a válaszok százalékában)

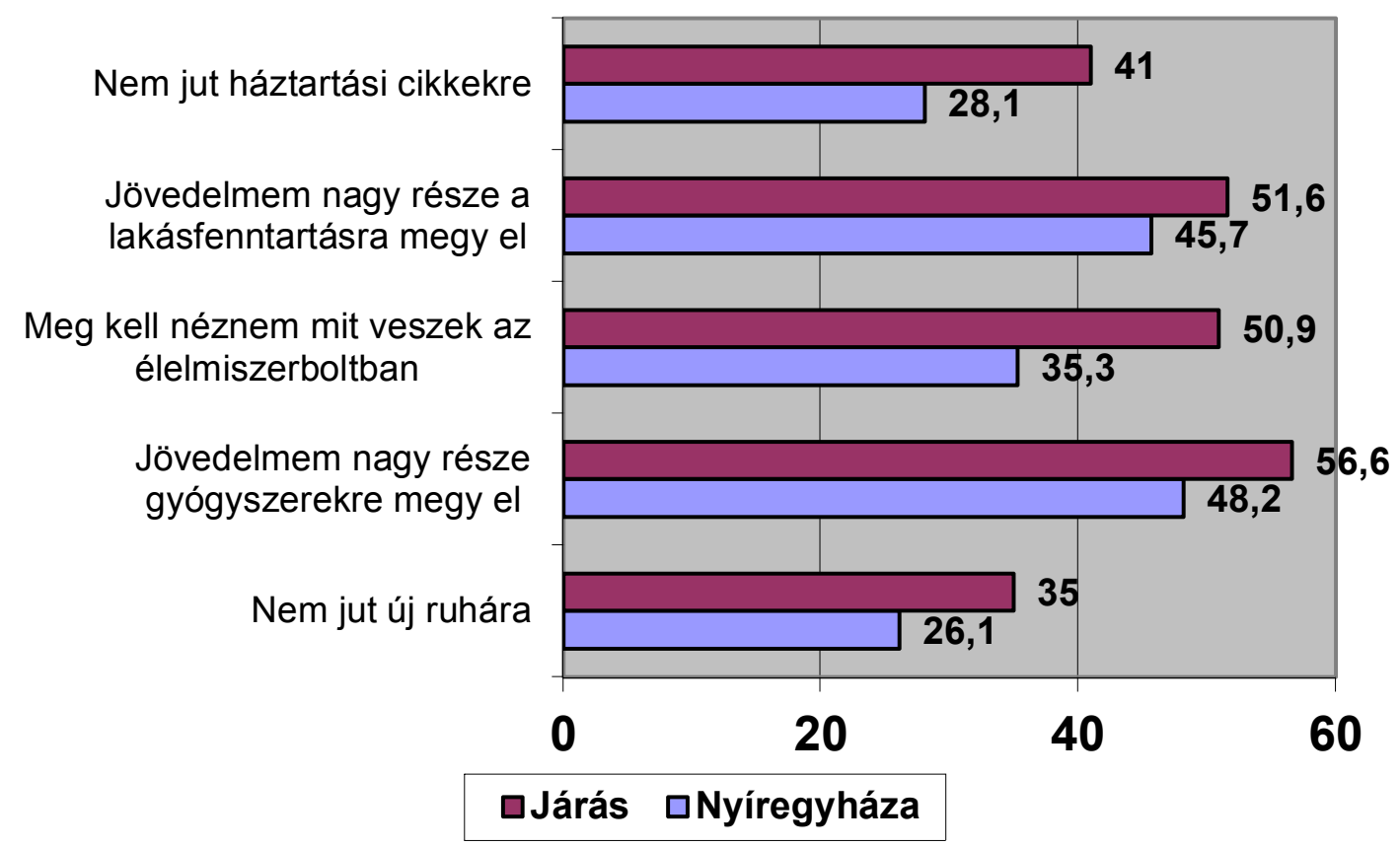

Forrás: Nyíregyháza Város Életminösége 2015, Nyíregyháza Járás Életminősége 2015. kutatások

A városban élő idősek legfájdalmasabb kiadásként a lakásfenntartás és a gyógyszer kiadások költségeit tekintik, míg a járási idősek az említettek mellett az élelmiszer kiadásokat is a megterhelő tételek között említették. Az áltagosan alacsonyabb jövedelmü járási lakosok sokkal megterhelőbbnek élték meg a fenti táblázatban összegzett kiadásokat, mint a nyíregyházi 65 év feletti lakosok.

\footnotetext{
${ }^{51}$ www.gfk.com
} 
6. sz. ábra: Időskorúakat tartalmazó háztartások jövedelmi helyzetének szubjektív megitélése (\%)

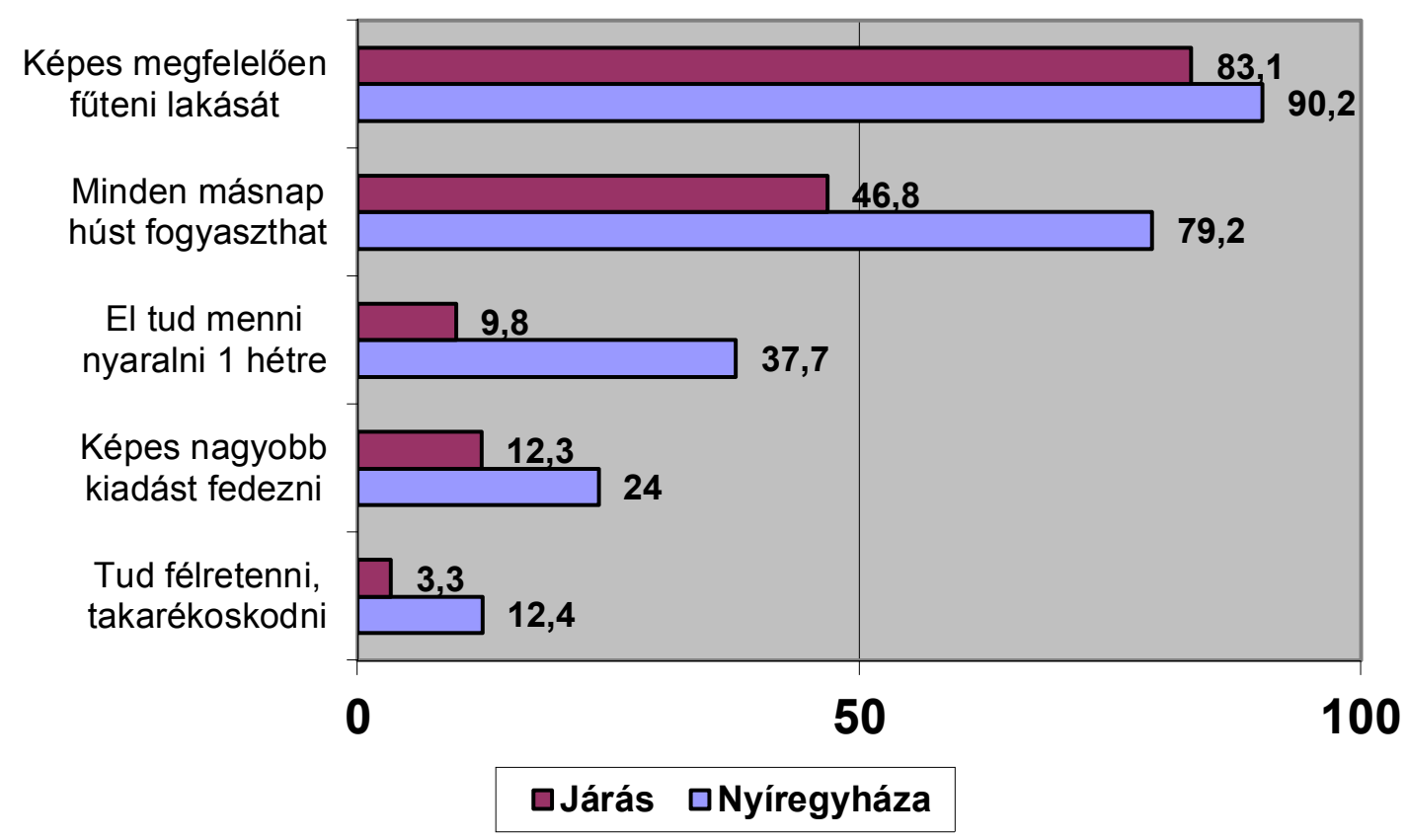

Forrás: Nyíregyháza Város Életminösége 2015, Nyíregyháza Járás Életminősége 2015. kutatások

A városi és a járási idősek fogyasztási szokásai leginkább az élelmiszerfogyasztás, a szabadidő, valamint a megtakarítások tekintetében mutatnak nagy eltéréseket. A járásban élők mintegy 3\%-a tud félretenni, takarékoskodni, így számukra komoly kihívást jelent egy-egy nem várt költség kifizetése. Egy évben egy hét nyaralást a megkérdezettek kevesebb, mint tizede engedhet meg magának. Az élelmiszerek fogyasztása tekintetében majdnem minden második idős válaszadónak kell mérlegelnie. Ezzel szemben a megyeszékhelyen élő időseknek átlagosan kedvezőbb anyagi helyzete.

\section{Egészségi állapot}

Korábbi vizsgálatok szerint az egészségi állapot romlásának szubjektív megítélése kevésbé határozza meg az idősek szubjektív életminőségét (Giczi, 2008), de az egészség romlásával együtt járó kapacitás korlátozódás annál inkább (Savikko és mtsai, 2005). Az érzék- és mozgásszervi problémák az idősek otthonukba záródásával járnak, mely erősíti a szociális kapcsolatok fellazulását éppen abban a helyzetben, amikor erre az idősnek a legnagyobb szüksége lenne. A 2011. évi cenzus adatai szerint (KSH, 2012) a fogyatékossággal élők 57\%-a 60 év feletti lakos volt. Az idősek kapacitásának korlátozódásáért ezen felül 40\%-ban a tartós betegségekkel való együttélés is felelős. 
7. sz. ábra: Az egészségi állapot szubjektív megitélése a csak időseket tartalmazó háztartásokban (\%)

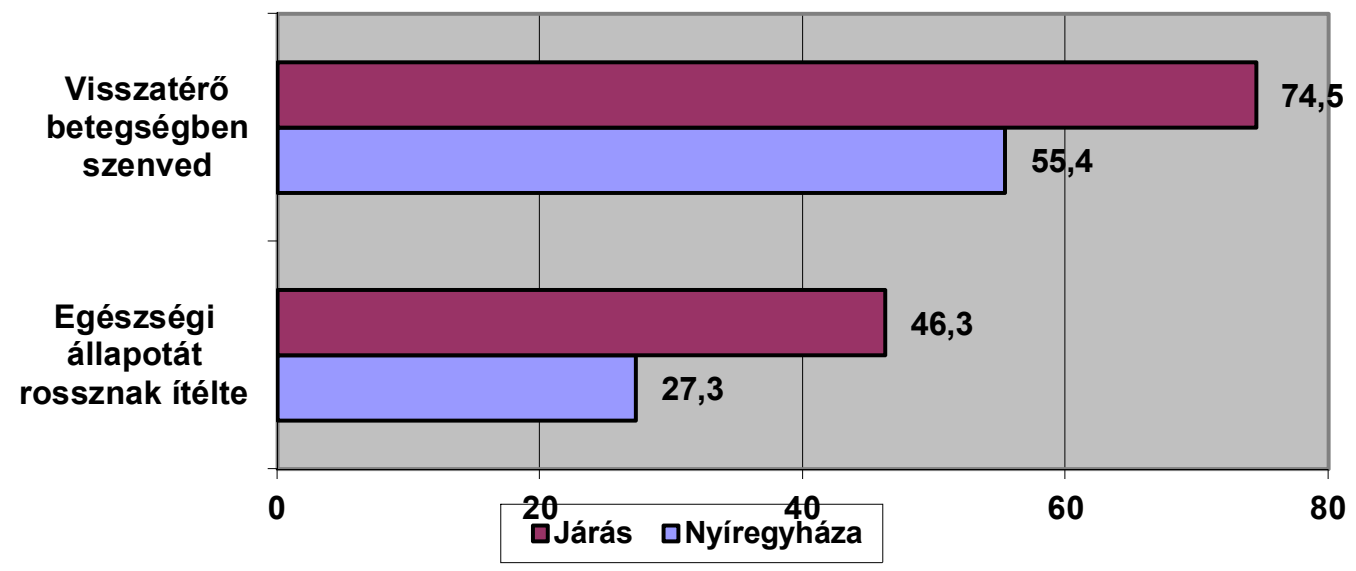

Forrás: Nyíregyháza Város Életminösége 2015, Nyíregyháza Járás Életminösége 2015. kutatások

A járási és a nyíregyházi időskorúak saját egészségi állapotuk megítélésében markáns eltérés tapasztalható, a vidékiek sokkal rosszabbnak ítélik egészségi állapotukat.

Az egészségügyi szolgáltatók és ellátások közül az idősek még mindig a háziorvosi szolgálattal tartják a legszorosabb kapcsolatot. A városi idős háztartásokban élők 88,4\%-a látogatta meg az előző 12 hónapban háziorvosát szemben a járásban élők 92,6\%-os arányával. Legalább havi rendszerességgel látogat el a háziorvosi rendelöbe a járási idősek 26,6\%-a és a nyíregyháziak 29,2\%-a. Minden huszadik járási és minden tizedik nyíregyházi időskorú gondolja úgy, hogy az orvos javaslata ellenére nem került egészségügyi szakellátásba. Az idősek több mint negyede töltött el legalább egy éjszakát a kórházban.

Összegezve megállapítható, hogy a két minta egészségi állapotában tapasztalt eltérések ellenére sem érzékelhető jelentős különbség az egészségügyi ellátáshoz történő hozzáférés jellemzőiben. Igaz ugyan, hogy a vidéki idősek inkább a háziorvos ellátását veszik igénybe, s ezzel szemben néhány százalékponttal elmarad a szakellátás igénybevételének aránya a városiakétól, ez azonban több okra is visszavezethető.

$\mathrm{Az}$ egészségügyi alapellátás hozzáférésével kapcsolatos kutatások szerint (Babusik, 2004), (Patyán és Fábián, 2014) a vidéki ellátás során a strukturális problémákon túl (hol van elérhető ellátás, ügyelet) számolni kell a háziorvosi praxisokban kialakult gyakorlat eltéréseivel is. Elképzelhető, hogy vidéken az orvos bizonyos esetekben azért nem utalja tovább az esetet, mert megítélése szerint az időskorú szállítása, utaztatása többet ártana, mint használna, és sok esetben maguk a paciensek is jobban preferálják a helyben történő ellátást.

Az egészségügyi szolgáltatások biztosításában továbbra is meghatározó szerepet tölt be a háziorvos vidéken és a nagyvárosban egyaránt. 
8. sz. ábra: Akadályozottsághoz kapcsolódó állitások megítélése a nyíregyházi és a járási csak időskorúakat tartalmazó háztartásfók válaszai alapján

(5 fokozatú Likert-skála átlag értékei alapján)
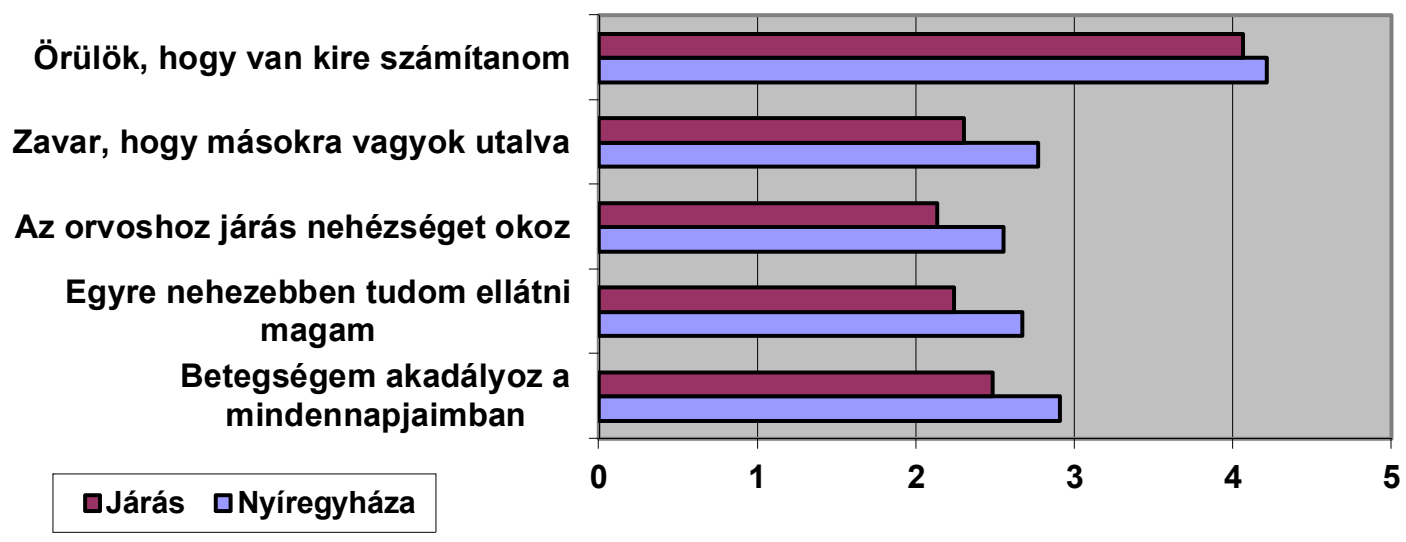

Forrás: Nyíregyháza Város Életminősége 2015, Nyíregyháza Járás Életminősége 2015. kutatások

A rosszabb anyagi helyzet és egészségi állapot ellenére a járási idősek kevésbé élik meg megterhelőnek akadályozottságukat.

\section{Aktivitás, tevékenységek iránti fogékonyság}

Az idősekkel kapcsolatos programok és helyi politikák egyik kulcskérdésévé kezd válni az aktivitás támogatása, fenntartása, erősítése az idősek körében. A panel kérdőív e témakört az akadályozottság, aktivitás, biztonság, részvétel és elidegenedés témakörökhöz kapcsolódó állítások értékelésével vizsgálja meg. ${ }^{52}$

9. sz. ábra: Az időskori aktivitáshoz kapcsolódó állitások megítélése a nyíregyházi és a járási csak idöseket tartalmazó háztartásokban (öt fokozatú Likert-skála átlagok)

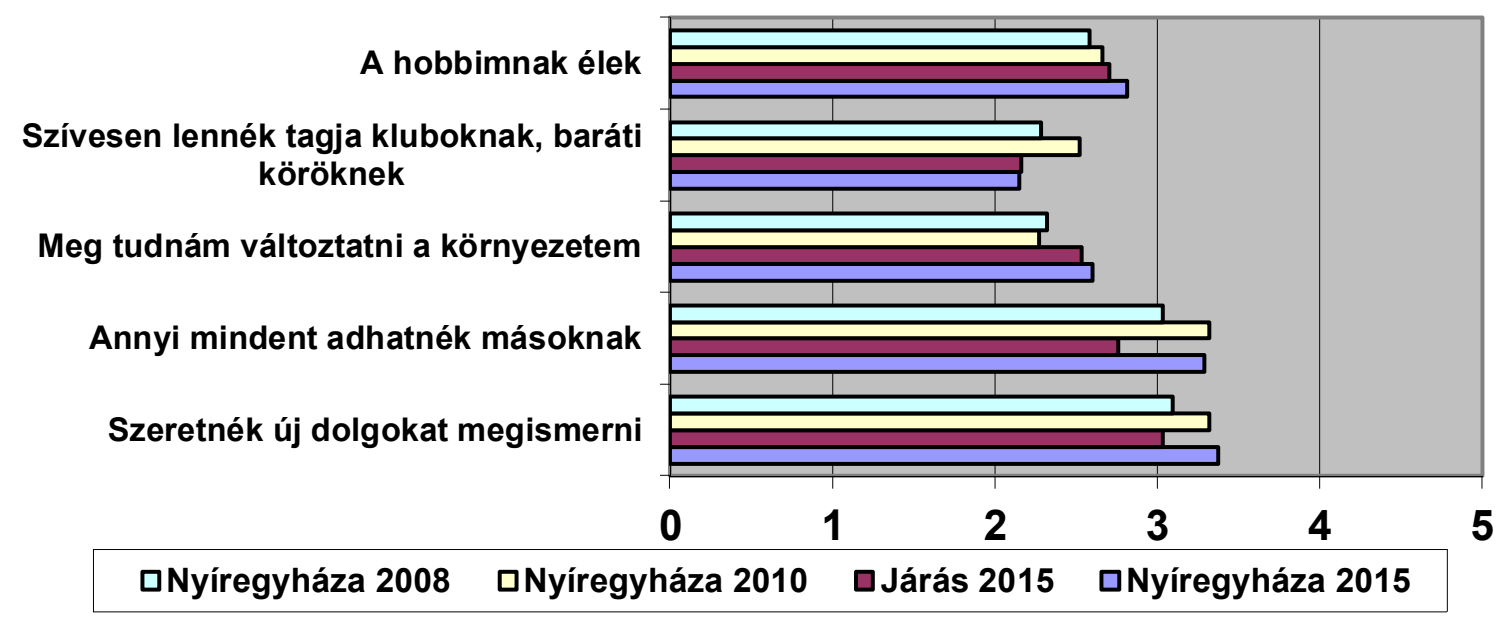

Forrás: Nyíregyháza Város Életminösége 2008, 2010, 2015, Nyíregyháza Járás Életminősége 2015. kutatások

${ }^{52}$ Az egyes kérdéscsoportokat a tanulmány 1. sz. melléklete tartalmazza. 
A megyeszékhely időskorú lakosságának aktivitással kapcsolatos vélekedését immáron 7 év távlatában vizsgálhatjuk. A válaszok átlagai ennek ellenére csak minimális emelkedést mutatnak. Korábbi elemzésünk (Patyán, 2014) során az aktivitást befolyásoló tényezők között meghatározónak találtuk az életkort és a magányt. Az időskori aktivitás az életkor elörehaladásával átlagosan csökken, és jellemzően alacsonyabb az egyedül élők körében. A járási idősek alacsonyabb aktivitást mutattak e kérdések összefüggésében. Az aktivitás természete, ha lassan is, de folyamatosan változik. A 9. sz. ábra jól mutatja, hogy az idősek életében az individuális aktivitás élménye iránti igény, vágy növekedett, míg a 2008. évihez képest is csökkent a közösségi aktivitás iránti vágy.

\section{Társas kapcsolatok, támogató hálózatok}

Az idősek életminőségét és mindennapi életét is meghatározza kapcsolatrendszerük. Az idősek kapcsolathálózata jellemzően átalakul, megváltozik a kapcsolatok száma és minősége egyaránt. A korábbi adatfelvétel elemzése szerint (Patyán, 2014), (Huszti, 2014) az életkor elörehaladásával csökken a gyenge kötésü kapcsolatok száma, és mindinkább felértékelődik a családi, rokoni kapcsolatok szerepe. A gyenge kötésű kapcsolatok (barát, ismerős, szomszéd) esetében a megmaradó kapcsolatoknak az idősek sokkal nagyobb jelentőséget tulajdonítanak. A barátok száma csökken és - különösen az önellátó képességében korlátozott idősek esetében - ezek a kapcsolatok sokkal inkább a fizikai közelségben lévő emberekre szorítkoznak, így nő a jelentősége a szomszéddal való kapcsolattartásnak is. A tartós betegséggel küzdő idősek esetében felerősödik, mondhatni kizárólagossá válik a családi kapcsolatok jelentősége (Patyán, 2014:133).

\section{Barátok, szomszédok az idősek életében}

Erre a kérdésre a városi mintába került idősek átlagosan 5,6 barátot jelöltek meg. Az egyedül vagy időskorú társával együtt élők 5,4 barátot jelöltek meg átlagosan. A járási mintában az idősek 3,6 főt, a csak időskorút tartalmazó háztartásokban élők 3,7 föt tartottak barátjuknak.

A városi idősek közel $60 \%$-ának egy-négy barátja van, míg a járásban élők kétharmada jelölt meg hasonló számú barátot kapcsolathálózatában.

Korábbi vizsgálataink szerint (Huszti, 2014:151) a hatvan év feletti korosztály 2008-ban átlagosan 3,5 (2008), illetve 3,6 (2010; 2012) föt jelölt meg barátjaként. Huszti Éva korábbi kutatási eredményi szerint a barátok számát többek között csökkenti a rossz szociális helyzet, az időskor, illetve az egyedül élés, ezzel szemben növelheti a barátok számát a jó anyagi helyzet, illetve a fiatalabb életkor. Mindezek mellett a barátok számának meghatározása szubjektív tényezőkön is múlik. Huszti Éva (2015) jelen kutatásunk kapcsolathálózati elemzését végezte, s a járási népesség körében szintén átlagosan alacsonyabb számú barátot talált, mint a városiak esetében. Elemzései szerint a batárok számát a fentieken túl az iskolai végzettség is befolyásolja. 
A városi mintában az idősek átlag 1,6, a járásban élő idősek átlag 1,4 olyan barátot jelöltek meg, akik egyben szomszédságukban is élnek. Ez tehát általánosságban egykét szomszédot jelenthet az esetek túlnyomó részében.

A kapcsolat jellegét és szorosságát az alábbi ábra szemlélteti:

10. sz. ábra: Milyen gyakran beszélget szomszédjaival?

(Egy és kétszemélyes időskorút tartalmazó háztartásban élök a válaszok\%-ában)

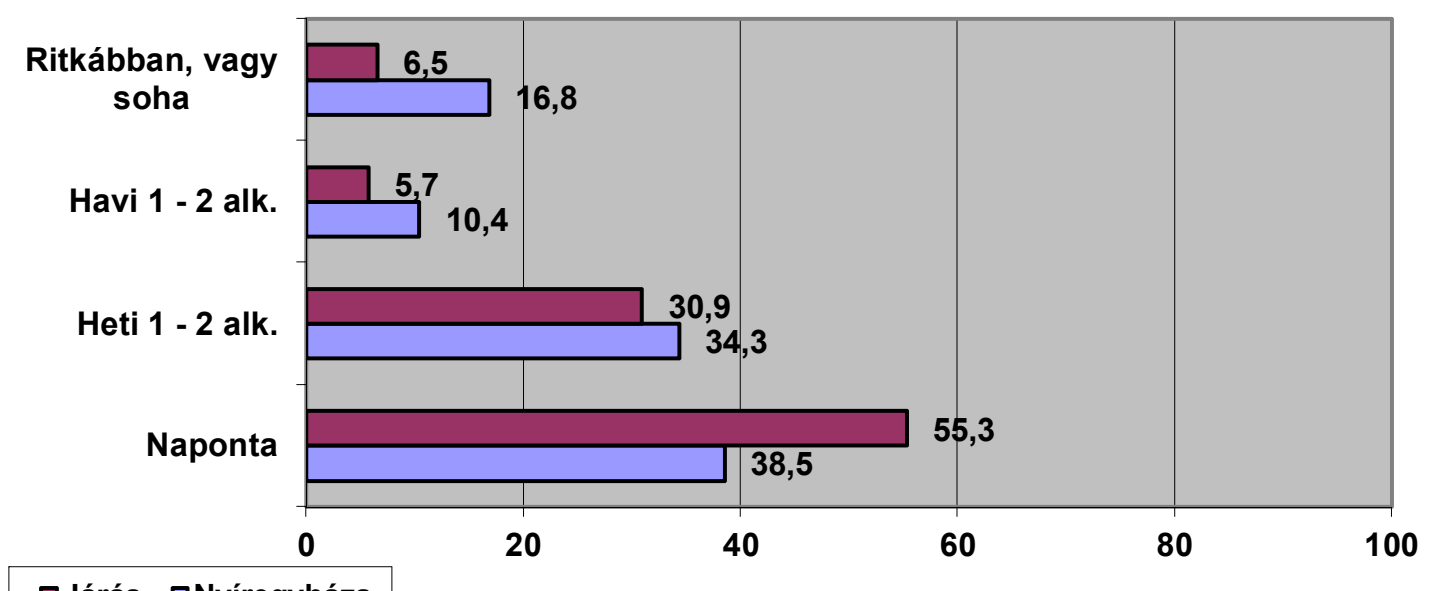

口Járás 口Nyíregyháza

Forrás: Nyíregyháza Város Életminösége 2015, Nyíregyháza Járás Életminősége 2015. kutatások

Annak ellenére, hogy az idősek baráti kapcsolatainak egy részét a szomszédjaik teszik ki, látható, hogy napi kapcsolathálózatukban is meghatározó jelentőséggel bírnak a szomszédsági kapcsolatok.

\section{1. sz. ábra: Milyen gyakran találkozik barátaival?}

(Egy és kétszemélyes időskorút tartalmazó háztartásban élök a válaszok\%-ában)

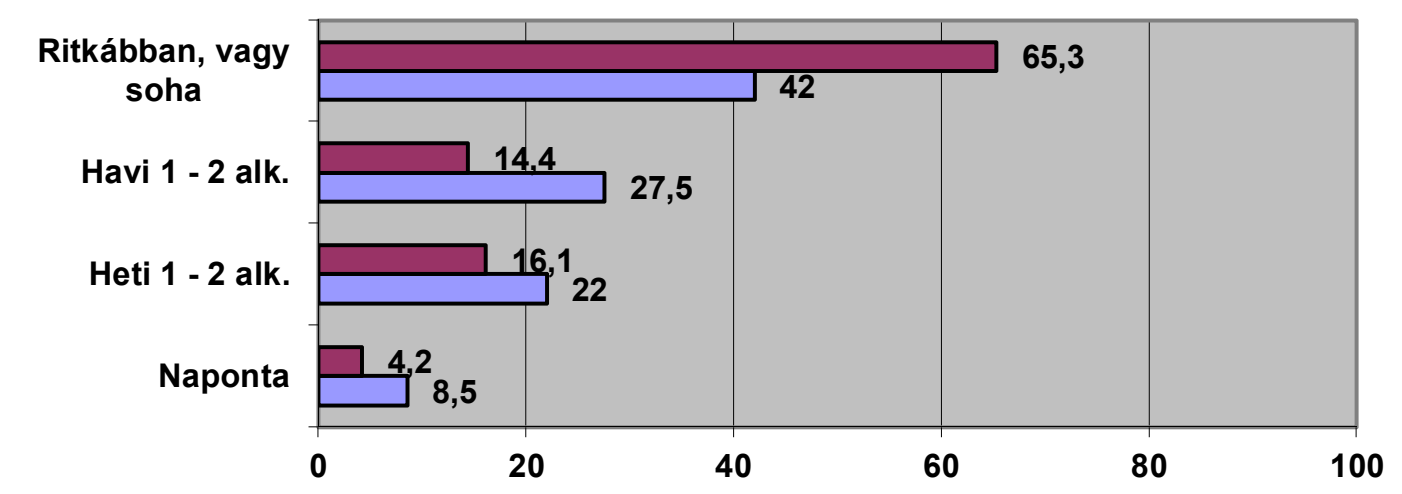

口Járás םNyíregyháza

Forrás: Nyíregyháza Város Életminősége 2015, Nyíregyháza Járás Életminősége 2015. kutatások 
A napi kapcsolatokat tehát erősen meghatározza az idősek szomszédjaikkal való viszonya. A városi idősek $42 \%$-a és a járásban élők 65\%-a egyáltalán nem vagy csak nagyon ritkán találkoznak barátaikkal. A rokonokkal való kapcsolat gyakorisága is hasonlóképpen alakult. A városi idősek 4,6\%-a találkozik naponta rokonaival, hetente is kevesebb, mint ötödük érintkezik a rokonokkal. A járásban élö idősek harmada kerül kapcsolatba hetente rokonaival.

12. sz. ábra: Kitöl számithat segítségre?

(Egy és kétszemélyes háztartásban élő idősek \%-ában)

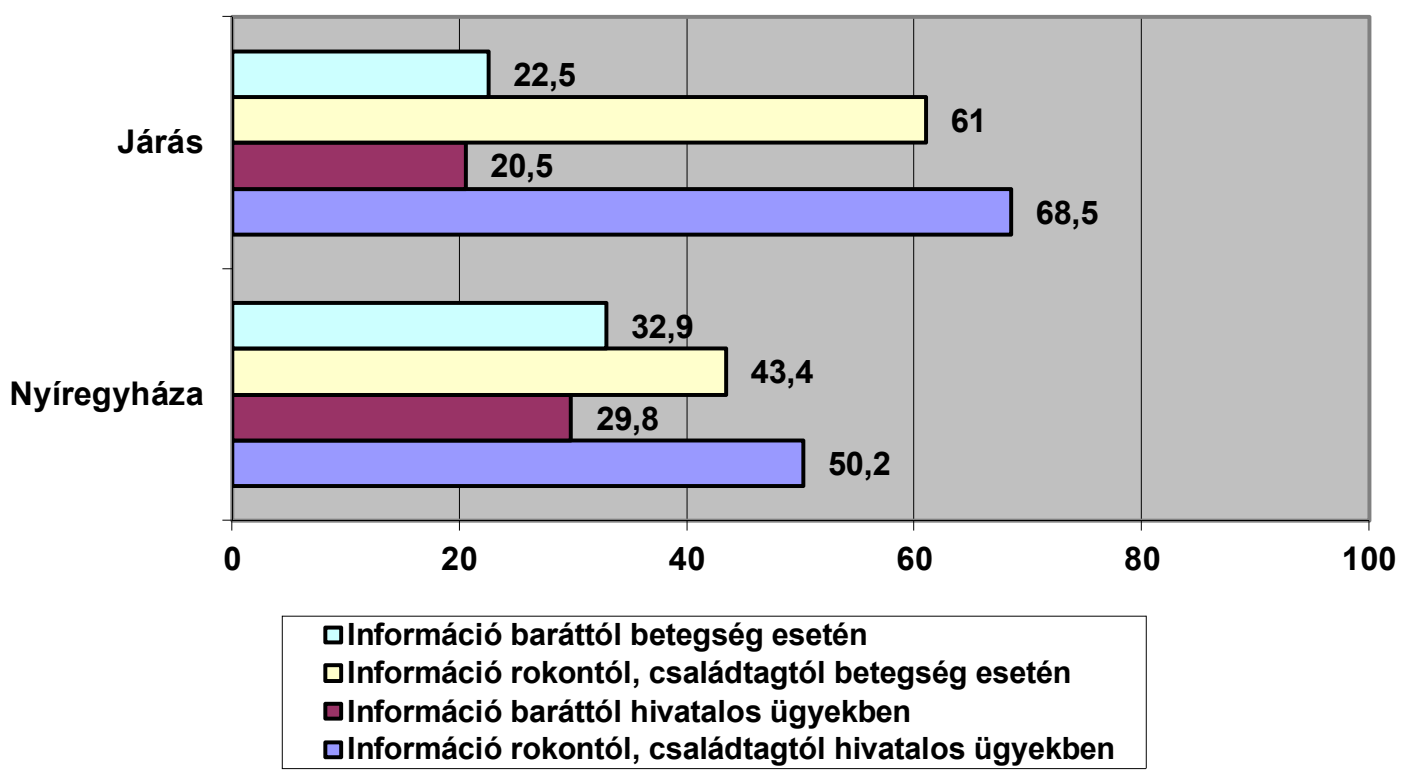

Forrás: Nyíregyháza Város Életminösége 2015, Nyiregyháza Járás Életminösége 2015. kutatások

Az idősek számára a család támogató szerepe továbbra is meghatározó jelentőséggel bír. A legerősebb támogató továbbra is a házastárs (város: 39,5\%; járás: 37,3\%), valamint a gyermek (város: $56 \%$; járás: 40,2\%). A korábbi adatfelvétel során a 65 évnél idősebbek 33\%-a nyilatkozta, hogy házastársára számít betegsége esetén, míg gyermeküket ilyen üggyel kapcsolatban $41 \%$ jelölte meg. A járásban élők szükebb kapcsolathálózata még jelentősebbé teszi az erős kötésü (családi, rokoni) kapcsolatok szerepét. A városi és a járási idősek kapcsolathálózatát összevetve szembetünő változást a szomszédra és a barátokra való támaszkodásban lehet látni. Az átlagosan magasabb számú baráttal rendelkező nyíregyházi idősek 6,9\%-a kér segítséget szomszédjaitól, 15,9\%-uk barátaiktól betegség esetén. Ez jelentős eltérés a 2008. évi adatfelvételhez képest, ahol még a nyíregyházi idősek $21 \%$-a számított baráti segítségre. Ezzel szemben a járási idősek egyaránt 2,9\% - 2,9\%-a keresné ez ügyben szomszédjait és barátait. 
13. sz. ábra: Társadalmi kapcsolatok jellege a csak idöskorú háztartásban élö nyíregyházi és vidéki válaszadók arányában (\%)

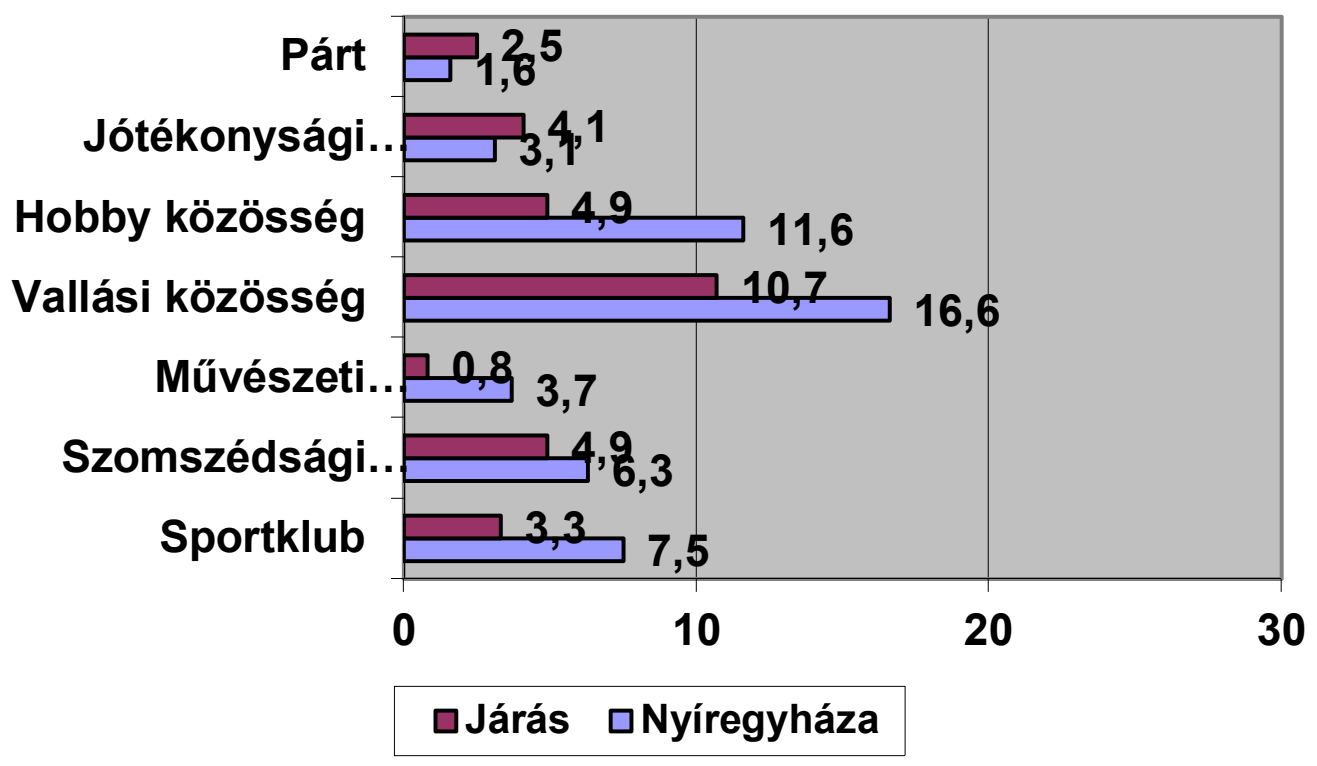

Forrás: Nyirregyháza Város Életminösége 2015, Nyíregyháza Járás Életminösége 2015. kutatások

A városi idősek a hobby, a szabadidős szervezetekben, a művészettel foglalkozó közösségekben, valamint a sportszerveződésekben a vidéken élő társaiktól sokkal nagyobb aktivitást mutatnak. Vallási közösségekhez való tartozás a városi lakosság körében sokkal jellemzőbb, mint a járásban lakók körében (Huszti, 2015). Ez a jelenség az idősek esetében még jellemzőbb. A városi idősek 18\%-a tartozott 2012ben. Ez az érték némiképp csökkenni látszik 2015-ben, s meglepő módon a járásban élő idősek mintegy 30\%-kal kevesebben kapcsolódnak egyházi közösségekhez.

\section{Lakás, otthon}

Az idősek lakhatásának szerepére több korábbi kutatási jelentésben is felhívtuk a figyelmet (Patyán, 2012, Patyán, 2014). Az idősek életében - nagyságán, felszereltségén, fizikai megfelelőségén túl - a lakás, mint otthon komoly jelentőséggel bír. Az idős ember élete, munkája az otthona, itt nőttek fel gyermekei, unokái, s az élet során megszerzett dolgok mind a lakásában teszik szimbolikussá életútját. Más korosztályokhoz képest a fizikai, önellátási kompetenciák korlátozódása újabb sajátos szereppel ruházza fel az otthon fogalmát. Idővel egyre nehezebb kimozdulni otthonukból, szükülni kezd a külső világ, míg felértékelődik a belső a maga fizikai és spirituális valójával. Megérthető tehát, hogy az otthon az idősek életminőségét befolyásoló tényező is egyben.

Korábbi felméréseink szerint az idősek Nyíregyháza városban relatíve nagyobb lakásokban laknak, mint az aktív korosztály tagjai. 
14. sz. ábra: Időskorú és nem idöskorú háztartások lakásnagysága (szoba, \%)

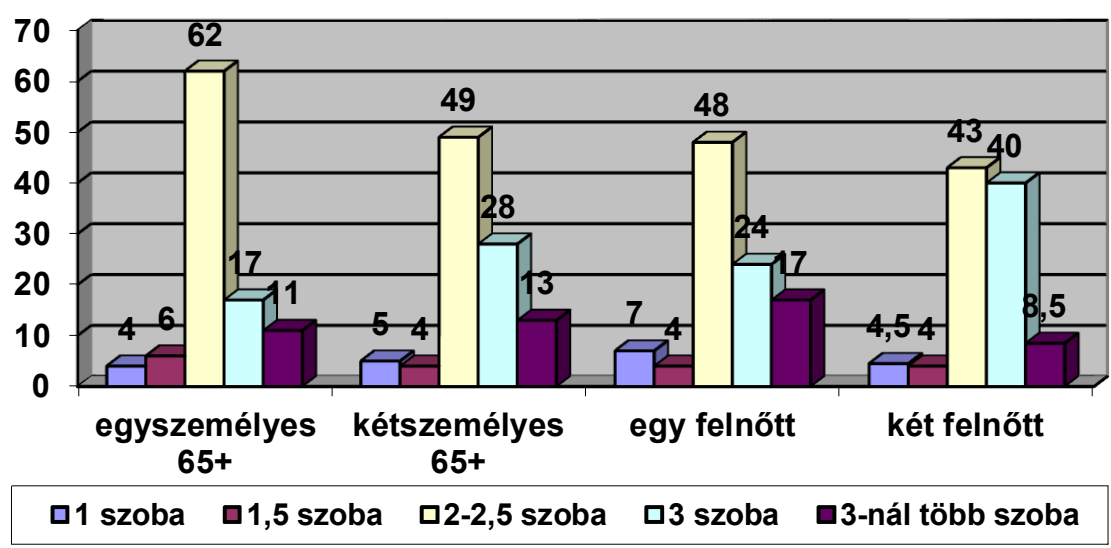

Forrás: Patyán (2010)

A relatíve nagyobb lakásban élés eredményeképp - valamint a biztos havi jövedelem következtében - az idősek jellemzően alacsonyabb számban vehették igénybe a lakhatást támogató szociális transzfer juttatásokat. Jelen vizsgálatunk lehetőséget biztosít arra, hogy a lakás nagyságát, megfelelöségét összehasonlítsuk a városi és a járási mintában.

15 sz. ábra: Lakásnagyság, szobaszám, egy háztartásban lakók átlaga a járásban és Nyirregyházán élö, csak időseket tartalmazó háztartásokban

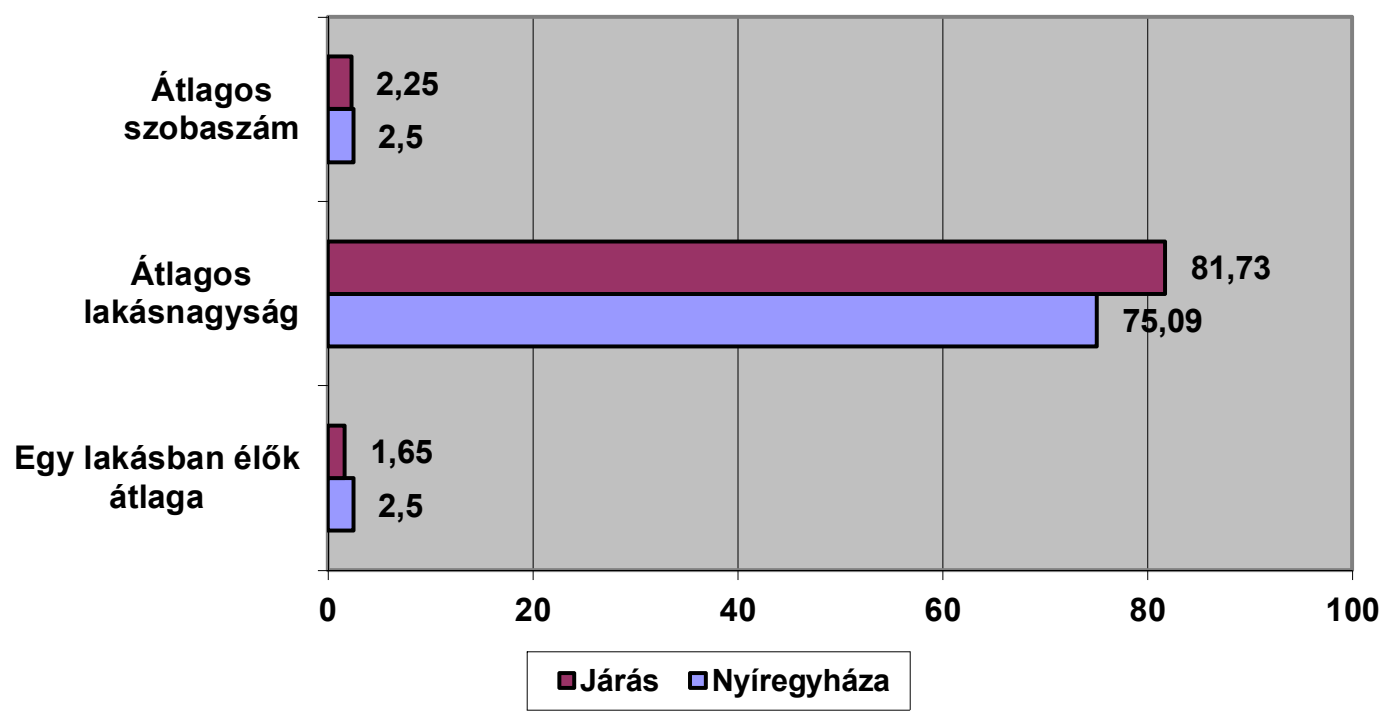

Forrás: Nyíregyháza Város Életminösége 2015, Nyíregyháza Járás Életminősége 2015. kutatások

Az átlagos lakásnagyság a városi nem időseket tartalmazó háztartások esetében 89,9 négyzetméter, az átlag szobaszám 3. Ebben átlagosan 3,84 fö lakik. Első látásra talán kicsit magasnak tünik ez a szám, de figyelembe véve, hogy az egyszemélyes háztartások jelentős részét idősek lakják, eredményeink a 2010. évi városi felmérés adatait tükrözik vissza. 
A járásban élök körében átlagosan nagyobb alapterületü lakásokra és az idősek esetében alacsonyabb laksürüségre bukkantunk. Az aktív korúak átlag 98 négyzetméteren élnek, míg az időskorú háztartások lakásnagysága 81,7 négyzetméter.

A városi idősek 15,3\%-a panaszkodott arra, hogy lakásának olyan problémája van, mely nehezíti a rendeltetésszerü használatot, a járásban ilyen problémát az idősek 18,5\%-a említett. A lakással tehát közel azonos mértékben elégedettek az idősek.

60. életévét követően a nyíregyházi idősek 11\%-a költözött. Ez az arány a járásban $9,6 \%$ volt.

\section{6. sz. ábra: A háztartások felszereltsége (a rendelkezésre állás százalékában)}

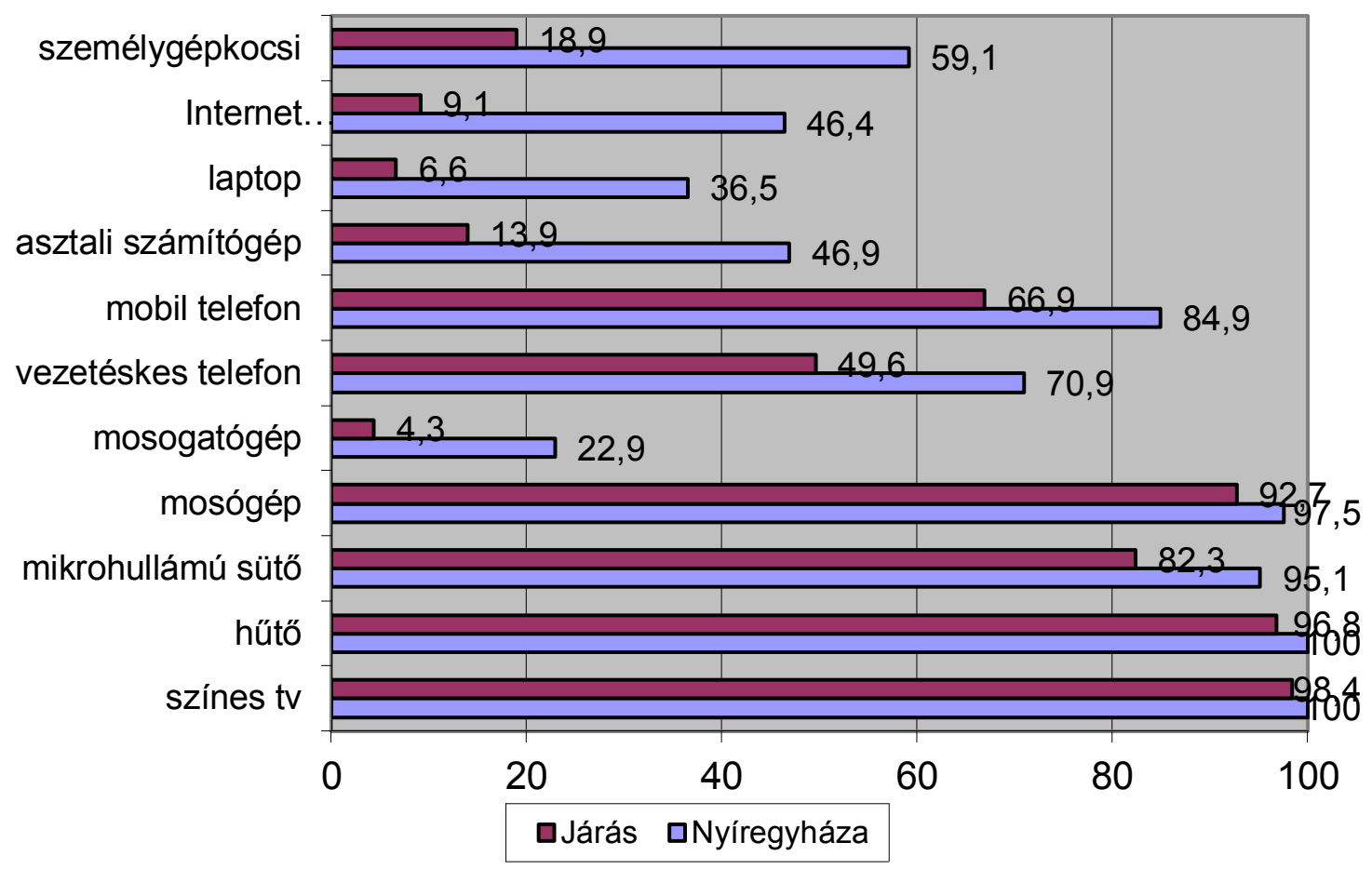

Forrás: Nyíregyháza Város Életminösége 2015, Nyíregyháza Járás Életminősége 2015. kutatások

Az egyes háztartási eszközökhöz való hozzáférést több tényező is meghatározhatja. A háztartások alapvető kellékei a televízió, a mosógép, valamint a hütőszekrény már csaknem minden háztartásban fellelhető. Ez utóbbi használati tárgy azonban hiányzik a járási idősek 7\%-ának lakásából. Legnagyobb eltérést a járási és a városi mintában mégis az infokommunikációt segítő eszközök és az Internet hozzáférésében lehet észlelni. A városi idősek körében ötször gyakoribb a szélessávú Internet hozzáférés esélye, mint vidéken. Az Internetezéshez szükséges eszközök birtoklásában hasonló az aránytalanság. Mobiltelefonnal a városi idősek $85 \%$-a rendelkezik, és vidéken is kedvező ez az arány, itt az idősek 67\%-a mobilozik.

Személygépkocsival a városi idősek majd' 60\%-a rendelkezik, míg vidéken mindössze kevesebb, mint a háztartások 19\%-a. A személygépkocsi birtoklása, 
fenntartása egyfelől a két mintában tapasztalt jövedelmi egyenlőtlenség következménye, másik oldalról viszont nehezítheti a közlekedést a gépkocsi hiánya.

\section{Összegzés}

Korábbi kutatásaink során érzékelhető volt a megye és a város lakosságának eltérő jövedelmi helyzete, fogyasztási jellemzői. Statisztikai értelemben a várost egy szigetként lehetett elképzelni, melyet a megye hátrányos mutatói emelnek ki. 2015ben első ízben nyílt lehetőség arra, hogy a városi adatbázist és a járásban élő lakosság helyzetét összevessük. Az idősek esetében ez számos - de nem túl meglepő eredményt mutatott.

Objektív mutatók tekintetében a járásban élők alacsonyabb keresetekkel és nyugdíjjal rendelkeznek, mint a nyíregyháziak. Az alacsonyabb nyugdíjak vélhetően a szignifikánsan alacsonyabb iskolai végzettséggel, valamint ennek következtében az alacsonyabb munkabérrel hozhatók összefüggésbe, mely a statisztikai adatok szerint megyénk sajátja.

Az alacsonyabb nyugdíj befolyásolja a fogyasztási kultúrát is. A járási időseknek sokkal inkább meg kell néznie, hogy mennyit költenek és mire. Jellemző, hogy a mindennapi kiadások, az élelmiszer, a gyógyszer költségek jelentenek a járásban élő időseknek nagyobb terhet. A járási idősek közül kevesek engedhetik meg maguknak a városi idős korosztályban gyakoribb fogyasztási szokásokat (pl. a nyaralás).

A két minta demográfiai hasonlatossága ellenére szembeöltő a járásban élők rosszabb egészségi állapota, melyet azonban szubjektíve nem élnek meg negatívabban a megyeszékhelyen élő idősektől. A támogató rendszerek tekintetében a járásban élők sokkal inkább a családra támaszkodnak, kevesebb baráttal rendelkeznek. A baráti kapcsolatokra a kutatás adatai szerint támogatóként inkább a városi lakosság számíthat. A járásban élő idősek intenzív kapcsolatot ápolnak szomszédjaikkal, de ez a kapcsolat nem teherbíró, segítség esetén inkább a család támogató erejére szorítkoznak.

A járási idősek esetében fokozottan jellemző a relatíve nagy lakás, s e mellett a háztartásban élők alacsony aránya, mely növelheti a lakhatásra fordítandó kiadásokat, ezáltal fokozottabb terhet ró az idősekre.

A járásban élö idősek háztartásaiban sokkal alacsonyabb arányban vannak jelen az infokommunikációt segítő eszközök, ez alól a mobiltelefon készülék képez kivételt.

A háztartások egy före eső átlagjövedelmében mért 15.000 Forintnyi különbség alapvetően meghatározza a vidéki idősek életmódját, fogyasztási szokásait. A jóléti rendszerek uniformizált segítségnyújtási formái esetében a vidék város különbségeket mindenképp figyelembe kellene venni.

\section{Irodalom:}

1. Babusik Ferenc (2004): Hozzáférési különbségek az egészségügyi alapellátásban I. Esély,4. sz. 71 -100 .

2. GICZI Johanna (2008): Szubjektív jólét időskorban in: Grádics Ágnes (szerk) Aktív időskor tanulmánykötet, KSH Budapest 
3. HUSZTI Éva (2015): Mondd meg kikkel töltöd az időset és megmondom ki vagy. A társas támogatást nyújtó személyes kapcsolati háló néhány jellemzője és müködése a Nyíregyházi járásban in: Acta Medicinae et Sociologica Vol. 6 No. 18-19.

4. HUSZTI Éva (2014): Társas kapcsolatok Nyíregyházán in: Acta Medicinae et Sociologica 2014. 12-13.szám.

5. HUSZTI Éva (2012): Társas kapcsolatok. Családi, rokoni, baráti kapcsolatok Nyíregyháza lakói körében in.Fábián - Patyán - Huszti (szerk) Életminőség Nyíregyházán 2008-2010. Acta Medicinae et Sociologica különszám. DE-EK Nyíregyháza 155-177.o.

6. KRIZSAI Anita - TÓTHNÉ CSATLÓS Ildikó (2015): Szociális problémák és a segélyezési rendszer átalakulása a Nyíregyházi járás településein in: Acta Medicinae et Sociologica Vol. 6 No. 18-19.

7. Malakucziné Póka Mária (2105): A Nyíregyházai járás települési szervezeti, demográfiai, háztartási jellemzői in: Acta Medicinae et Sociologica Vol. 6 No. 18-19.

8. PATYÁN László (2014): Egyszemélyes háztartásban élő idősek életminősége in: Acta Medicina et Sociologica 12 - 13. szám DE EK Nyíregyháza, 123 - 141. ISSN: 2062-0284

9. PATYÁN László, FÁBIÁN Gergely (2014): Characteristics of elderly people's access to social services. In: Access to Services in Rural Areas: a Comparison of Finland and Hungary / by Ferenc Bódi, Europäischer Hochschulverlag GmbH, Bremen, 154-159,

10. PATYÁN László (2012): Időskorúak életminősége 2010. in: Életminőség Nyíregyházán 2008 2010. (szerk: Fábián - Patyán - Huszti) DE EK, Nyíregyháza ISSN 2063-3572 117- 135.o.

11. PATYÁN László (2010): Időskorúak Nyíregyházán, Szabolcs - Szatmár - Beregi Szemle 2. p. 237 $-254$

12. SAVIKKO, N - ROUTASALO, P. - TILVIS R. S. - STRANBERG T. E.- PITKALA K.H. (2005): Predictors and Subjective Causes of Loneliness in an Aged Population, Archives of Gerontology and Geriatrics 41. Elsevier Ireland Ltd.

\section{Internetes források}

1. Központi Statisztikai Hivatal: A népesség gyarapodó rétege. Az időskorúak jellemzői 2014. október. http://www.ksh.hu/docs/hun/xftp/idoszaki/pdf/nepesseg_gyarapodo.pdf Utolsó letöltés: 2015. szeptember 12.

2. GVK: Többet teszünk egészségünkért a válság idején 2012. WWw.gvk.com

Utolsó letöltés: 2015. október 22.

\section{I. sz. melléklet}

\section{Akadályozottság kérdéscsoport}

- Betegségem akadályoz a mindennapjaimban

- $\quad$ Egyre nehezebben tudom magam ellátni

- Az orvoshoz jutás nagy nehézséget okoz

- Örülök, hogy van kire számítanom

- Zavar, hogy másokra vagyok utalva

\section{Aktivitás, részvétel}

- Úgy érzem, meghallgatnak, számít a véleményem

- Szerintem a társadalomban az idősek megkapják a nekik járó tiszteletet, megbecsülést

- Szerintem többet kellene az idősekkel foglalkozni 
- $\quad$ Szeretnék új dolgokat megismerni

- Annyi mindent adhatnék másoknak

- Meg tudnám változtatni a környezetem

- Szívesen lennék tagja kluboknak, baráti köröknek

- A hobbymnak tudok élni

\section{Biztonság}

- Gyakran félek egyedül

- Örülök, hogy biztos jövedelemmel rendelkezem

- Érzem, hogy családom szeret, megbecsül engem

\section{Elidegenedés}

- A modern világ dolgaiban nehezen tudok eligazodni

- Nyugdíjazás után az ember már nem való semmire

\section{A szerző}

Patyán László szociális munkás, Debreceni Egyetem Egészségügyi Kar, főiskolai docens 